\title{
Tissue Preservation Index (TPI) and Gelification Index (GI) with the Quality of Coal as well as the Connection to the Acid Water Mining
}

\author{
Muhammad Ilham Fatkhurrahman ${ }^{1 *}$, Dian Agus Widiarso. ${ }^{1}$, Devina Trisnawati ${ }^{1}$, Ahmad \\ Zaki Romi ${ }^{2}$, dan Arya Gustifram ${ }^{2}$ \\ ${ }^{1}$ Geological Engineering, Diponegoro University, Semarang, Central Java, Indonesia \\ ${ }^{2}$ PT. Bukit Asam Tbk, Tanjung Enim, South Sumatera, Indonesia
}

\begin{abstract}
Tissue Preservation Index (TPI) and Gelification Index (GI) are products in coal related to the quality of coal and acid water mining. Research is conducted to know the relationship between the two by means of correlation using polynomial method and pressing method on the environmental diagram of the depositional environtment/facies. The correlation result is obtained that the higher the value of TPI, the value of Inherent Moisture and Volatile Matter is lower and the value of ash content and Fixed Carbon is higher. The higher the value of the GI, then the value of ash content and Fixed Carbon is higher and the value of Volatile Matter is getting lower. The lymnic deposition facies are areas that are located far from the sea and covered by a barrier and composed of land sediment with an active hydrological system. This is what causes minimal acidic water to occur because the sea sulfide does not intervene in the surrounding rocks. In addition, high GI value levels in the research area cause the oxidation process to be low and result in low rock acidity conditions.
\end{abstract}

\section{Introduction}

Acid Water Mining is a part of the process of mining where rock acidity is the result of oxidized minerals. It is related to the environment in which the coal is being deposited. Degrees of plant humification or Tissue Preservation Index (TPI) and environmental humidity conditions or Gelification Index (GI) have a relationship in determining the environment of coal deposition and still have an influence on the quality of coal. This research was conducted at Air Laya Mining Area PT. Bukit Asam Tbk, Tanjung Enim, South Sumatera by using a correlation method according to Sarwono (2006). The results of this research aims to provide an overview of TPI and GI relationship with the quality of coal as well as the acid water related to mine.

*Corresponding author : ilhamfatkhur98@gmail.com 


\section{Regional Geology}

The research area is part of the Muara Enim Formation (Fig. 1), where the formation is aligned above the Air Benakat Formation [9]. The formation of Muara Enim with a thickness ranging from $450-1200 \mathrm{~m}$ has an age between the Upper Miocene-Pliocene. In addition, the Muara Enim Formation is precipitized on the shallow, delta and non-marine regions. The formation is characterized by rocks in the form of sandstone, siltstone, claystone, and coal and on the upper part of the formation is often crushed by tuffaceous.

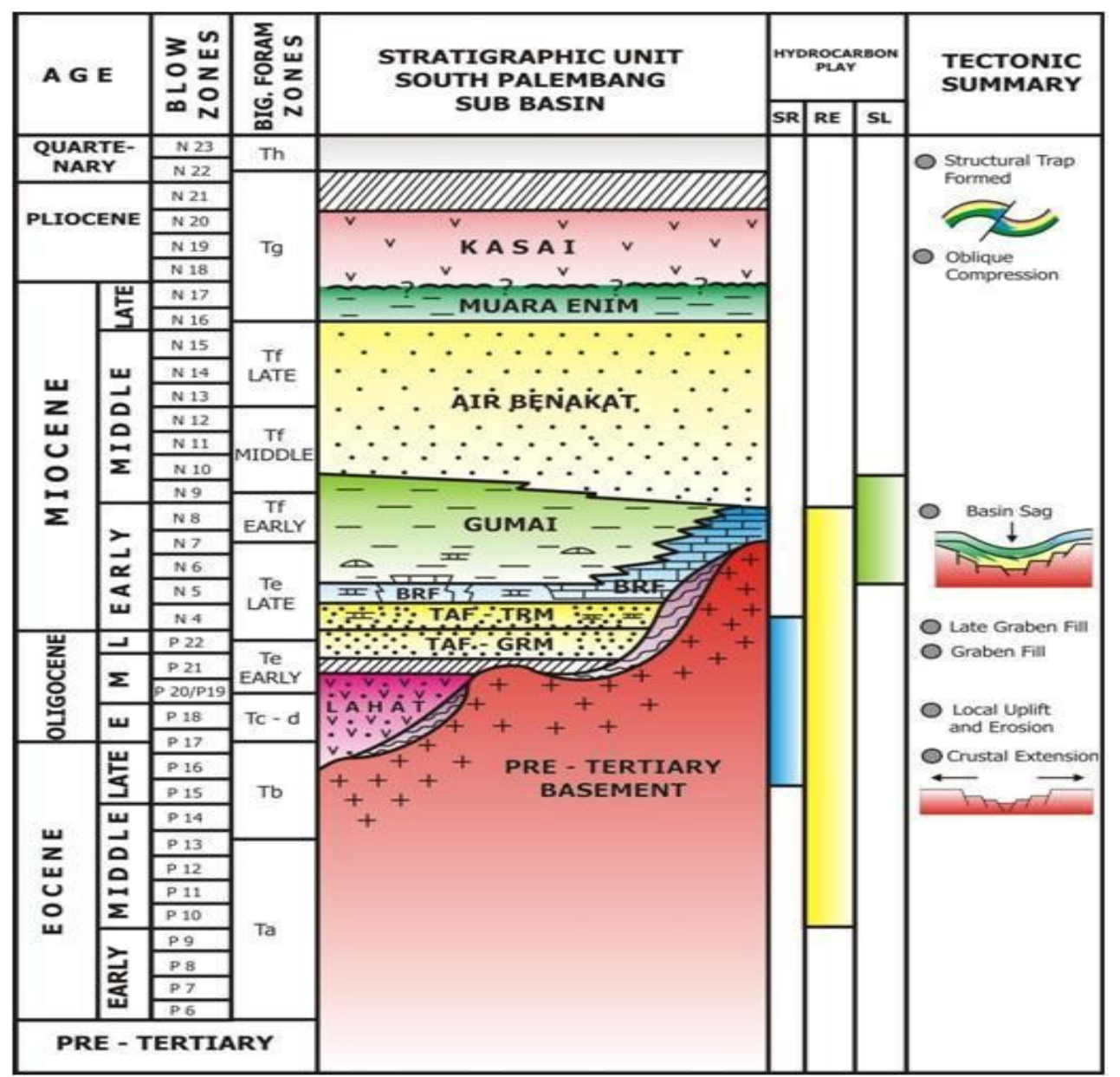

Fig. 1. Regional stratigraphy column of South Sumatera Basin [9].

\section{Literature Study}

\subsection{TPI and GI Maceral}

Tissue Preservation Index (TPI) is a comparison of the network structure on the maceral that is preserved with the unpreserved. In the process of the processing, the TPI value indicates the degree of humification in the Peatland area. Generally, cell destruction occurs due to high degree of humification. The greater the value of TPI showing the high presentation of wooden 
plants, shown by the high presentation Telovitrinite [2]. Gelification Index (GI) is a comparison of the maceral formed during the process of the purification with a maceral formed during the oxidation process. GI is associated with the continuity of humidity in peatlands. The smaller the GI price then the higher the oxidation rate [2]. According to Diessel (1992), the coal deposition environment can be determined based on the value of Tissue Preservation Index (TPI) and Gelification Index (GI).

\subsection{Coal Depositional Environment}

Lower Delta Plain environment, according to Horne (1978), the coal that is deposited in this environment has a wide spread but the thin thickness, it contains low inertinite with a high GI value. The content of Vitrinite / huminite in coal is dominated by detrovitrinite/ humotellinite so as to tend to lower TPI value. This suggests that the proportion of soft tissue of plants is high as well as experiencing biodegradation at relatively high $\mathrm{pH}$.

Limnic is a swamp environment that is composed of bush vegetation and grass in freshwater areas and is not affected by sea water. When adjacent to the sea water, it will be separated by a level or elevation that is impermeable in the form of a barrier.

\subsection{Coal Quality}

According to Sukandarrumidi, (1995), a determinant or parameter which is an analysis of the quality of coal is generally a lot of use of proximate analysis, in which this analysis describes a coal is a mixture (heterogeneous) of mild organic compounds or flying substances (VM= Volatile Matter) consisting of vapors and gases that come out when heated to a certain temperature with no contact from the oxygen.

Inherent moisture is a water content that is chemically bonded in coal and without any special drying can not evaporate.

Ash is the residual ash of combustion when coal is burned perfectly. In this case ash is actually called mineral matter because in general coal does not contain ash.

Coal has a flying substance that is usually termed as volatile matter (VM). It is generally a hydrocarbon methane gas derived from a fraction of the structure of the afiatic chain of coal molecules.

Fixed Carbon is one of the parameters that is determined based on the difference in the amount of moisture, ash, and volatile matter. Unlike the total carbon in the analysis of Ultimate, fixed carbon is obtained during the process of heating with a temperature that is said to be equivalent to volatile temperature matter when not evaporated, when evaporated then called volatile matter.

Energy or can be said to be a Calorific Value (CV) is an important parameter in coaland basically coal consumers need its energy power (CV). Energy required depends on the targeted energy capacity and must comply with the boiler design/capacity of an industry.

\subsection{Acid Water Mining}

Acid Water Mining is a water that has acid characteristics that usually formed at a mining site with a low $\mathrm{pH}(\mathrm{pH}<4.5)$. The formation of mine acid water is influenced by three factors, namely water, oxygen, and rocks containing sulfide minerals such as pyrite, calcopirite, Marcasite, etc. [5]. Acidic water is potentially polluting surface and groundwater.

Acidic water is formed when the sulfide minerals in the rocks appear on the surface in the oxidation state. Many types of sulfide minerals, iron sulfide are often found in coal dominated by pyrite and Marcasite [5]. All sulfide minerals may be present, iron sulfide is the main thing and acid producer is mainly [5]. 
The negative impact of the acidic water is the most important is for the water [5], which is the decrease of water quality (cloudy/colored). In addition, the impact on the area around mining can also be experienced in the form of reduced water organisms and damage to the operational means of mines [4].

\subsection{Corelation Study}

Correlation is an analytical technique that is included in any of the measurement of association..

Correlation coefficient is a statistical measurement of covariants or associations between two variables. The size of the correlation coefficient ranges between +1 to -1 . The Correlation coefficient shows the strength of linear relations and the direction of two randomized variables. According to Sarwono (2006) The strength of the relationship/correlation can be said: 1) 0 : There is no correlation between the two variables; 2) $>0-0.25$ : correlation is very weak; 3 ) $>0.25-0.5$ : enough correlation. 4) $>0.5-0.75$ : strong correlation; 5) $>0.75-0.99$ : Correlation is very strong; 6) 1 : ThePerfect correlation. The strength of the correlation of both relationships can be seen with the number of correlation coefficient of calculation result, among others: 1) When the value of the correlation coefficient is 0 , then both variables do not indicate the existence of a relationship; 2) When the value of the correlation coefficient approaches 1 , then both variables indicate a stronger relationship; 3) When the value of the correlation coefficient approaches 0 , then both variables indicate a weaker relationship. 4) When the value of the correlation coefficient equals 1 , then both variables indicate a perfectly positive linear relationship; 5) When the value of the correlation coefficient is equal to- 1 , then both variables indicate a perfect negative linear relationship.

\section{Methodology}

The study used some of the maceral data from several drill points in the Air Laya Mine Area. The drill points used are TS-14, TS-15, TS-20, TS-21, TS-23, and TS-24 (Fig. 2). The Maceral data is then analyzed using calculations in general to find the TPI-GI value. The next analysis is to use Excel 2016 software with reference to a trendline polynomial method. TPIGI data is further linked with coal quality test result data, while determining the correlation value, used the correlation coefficient according to Sarwono (2006).

The conclusion in this study was done by interpretation based on the correlation that has been obtained and based on linkage with the geological process of research area. 


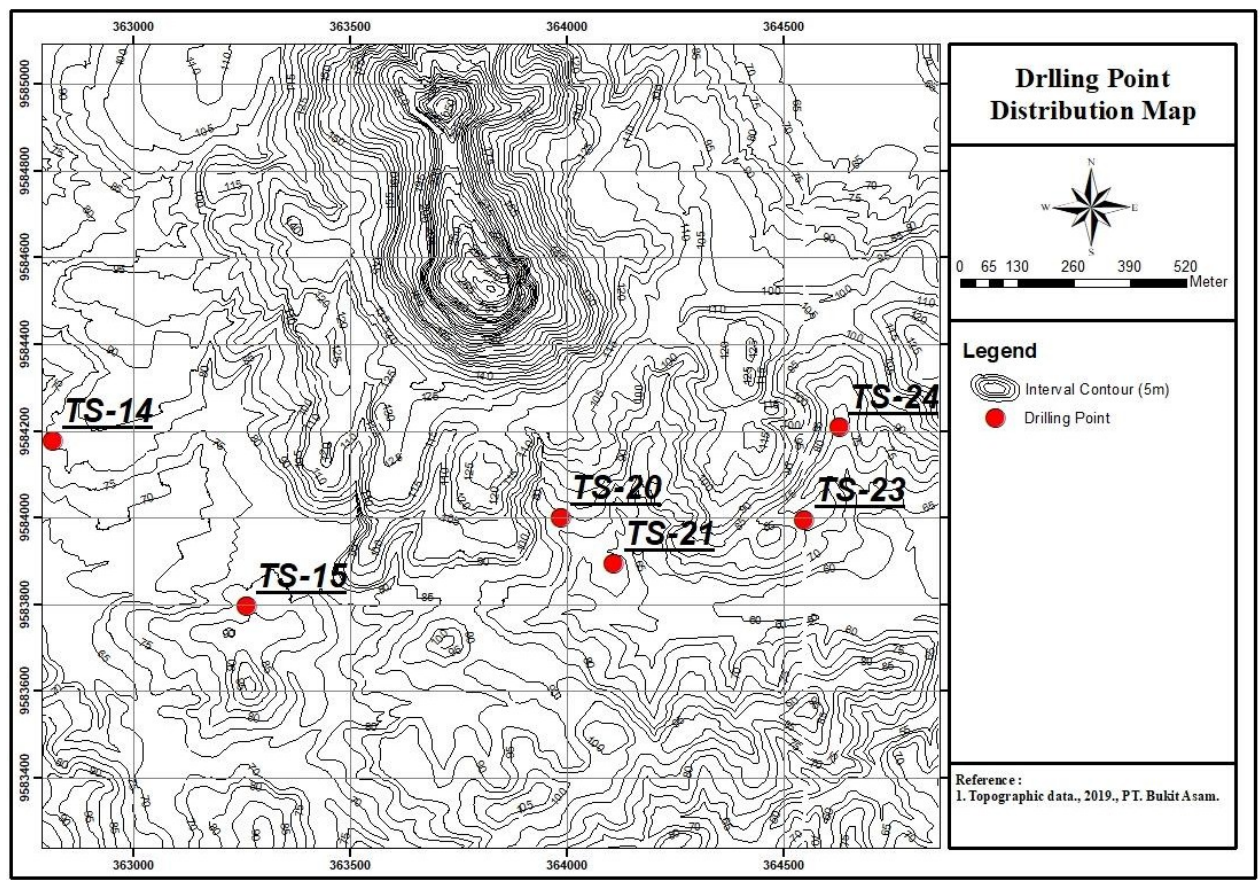

Fig. 2. Drilling Point Distribution Map

\section{Results and Discussion}

\subsection{Maceral Analysis}

The maceral that has been analyzed is grouped according to the state of the Air Laya Mining Area of the TS-14, TS-15, TS-20, TS-21, TS-23, and TS-24. The results of the analysis show the value of TPI ranging from $0.16-1.17$, and the GI value ranges from $0-8.04$ (Table. 1 ). 
Table 1. Results of the Maceral TPI, GI, GWI, and VI of Air Laya's Mining Area

\begin{tabular}{|c|c|c|c|}
\hline ID-BOR & Seam & TPI & GI \\
\hline Composite TS-14 & \multirow{4}{*}{ Seam A1 } & 0,30 & 3,21 \\
\hline Composite TS-15 & & 0,19 & 4,25 \\
\hline Composite TS-20 & & 0,16 & 5,78 \\
\hline Composite TS-21 & & 0,39 & 5,14 \\
\hline Composite TS-14 & \multirow{4}{*}{ Seam A2 } & 0,18 & 6,56 \\
\hline Composite TS-15 & & 0,21 & 4,57 \\
\hline Composite TS-20 & & 0,34 & 2,39 \\
\hline TS-21 & & 0,28 & 4,55 \\
\hline Composite TS-14 & \multirow{3}{*}{ Seam B } & 0,30 & 5,43 \\
\hline TS-15 & & 0,17 & 4,66 \\
\hline Composite TS-21 & & 0,25 & 4,34 \\
\hline Composite TS-20 & \multirow{2}{*}{ Seam B1 } & 0,31 & 3,44 \\
\hline TS-23 & & 0,17 & 4,41 \\
\hline TS-20 & \multirow{3}{*}{ Seam B2 } & 0,67 & 3,95 \\
\hline TS-23 & & 0,24 & 6,09 \\
\hline TS-24 & & 1,17 & 0,00 \\
\hline Composite TS-14 & \multirow{3}{*}{ Seam C } & 0,36 & 3,70 \\
\hline TS-15 & & 0,23 & 5,37 \\
\hline TS-21 & & 0,62 & 8,04 \\
\hline
\end{tabular}

\subsection{Coal Quality}

Analysis of coal quality, obtained data in the form of proximate test result through laboratory test with some parameters used namely Inherent Moisture range from $0.78-9.04 \%$, Volatile Matter ranges from 17.86-43.85\%, Fixed Carbon ranges from 33.66-60.36\%, Ash Content ranges from 3.32-28.54\% and Calorivic Value ranges from $4903-7540 \mathrm{Ccal} / \mathrm{g}$ (Table. 2). 
Table 2. The result of coal quality test of Air Laya's Mining Site

\begin{tabular}{|c|c|c|c|c|c|c|}
\hline ID-BOR & Seam & $\begin{array}{c}\text { IM Adb } \\
(\%)\end{array}$ & $\begin{array}{c}\text { Ash Adb } \\
(\%)\end{array}$ & $\begin{array}{c}\text { VM Adb } \\
(\%)\end{array}$ & $\begin{array}{c}\mathrm{FC} \mathrm{adb} \\
(\%)\end{array}$ & $\mathrm{Ccal} / \mathrm{g}$ \\
\hline Composite TS-14 & \multirow{4}{*}{$\begin{array}{c}\text { Seam } \\
\text { A1 }\end{array}$} & 9,04 & 9,76 & 39,49 & 41,71 & 6167 \\
\hline Composite TS-15 & & 4,82 & 28,54 & 32,98 & 33,66 & 4903 \\
\hline Composite TS-20 & & 8,83 & 9,74 & 39,14 & 42,29 & 6212 \\
\hline Composite TS-21 & & 7,5 & 6,8 & 40,84 & 44,86 & 6645 \\
\hline Composite TS-14 & \multirow{4}{*}{$\begin{array}{c}\text { Seam } \\
\text { A2 }\end{array}$} & 5,59 & 9,76 & 39,49 & 41,71 & 6167 \\
\hline Composite TS-15 & & 3,82 & 5,71 & 41,47 & 49,00 & 6998 \\
\hline Composite TS-20 & & 7,2 & 3,97 & 41,71 & 47,12 & 6908 \\
\hline TS-21 & & 5,77 & 3,32 & 41,26 & 49,65 & 7239 \\
\hline Composite TS-14 & \multirow{3}{*}{$\begin{array}{c}\text { Seam } \\
\text { B }\end{array}$} & 8,89 & 5,35 & 40,62 & 45,14 & 6662 \\
\hline TS-15 & & 5,50 & 6,30 & 41,82 & 46,38 & 6767 \\
\hline Composite TS-21 & & 4,11 & 5,95 & 39,1 & 50,84 & 7254 \\
\hline Composite TS-20 & \multirow{2}{*}{$\begin{array}{c}\text { Seam } \\
\text { B1 }\end{array}$} & 5,05 & 6,82 & 40,28 & 47,85 & 7015 \\
\hline TS-23 & & 2,58 & 7,62 & 36,79 & 53,01 & 7326 \\
\hline TS-20 & \multirow{3}{*}{$\begin{array}{c}\text { Seam } \\
\text { B2 }\end{array}$} & 2,85 & 12,59 & 37,14 & 47,42 & 6725 \\
\hline TS-23 & & 1,47 & 7,77 & 36,13 & 54,63 & 7540 \\
\hline TS-24 & & 0,78 & 21 & 17,86 & 60,36 & 6701 \\
\hline Composite TS-14 & \multirow{3}{*}{$\begin{array}{c}\text { Seam } \\
\text { C }\end{array}$} & 8,74 & 5,64 & 40,21 & 45,41 & 6909 \\
\hline TS-15 & & 6,22 & 4,71 & 43,85 & 45,22 & 6902 \\
\hline TS-21 & & 2,44 & 11,3 & 35,62 & 50,64 & 7024 \\
\hline
\end{tabular}

\subsection{Depositional Environment Interpretation}

The coal mining Area of Air Laya mine is the facies of Limnic (Fig. 3), this is evidenced by the high value of the GI and the low value of TPI (table. 1) and Ash content (table. 2). The high value of the GI with the low TPI value and ash content indicates that the coal-forming material is herbaceous plants in a persistent wet condition [1]. Limnic facies is a facies in the form of freshwater environments where the environment is not affected by the presence of sea water. This environment is the environment behind the barrier that is impermeable and adjacent to the Lower Delta Plain [8]. 


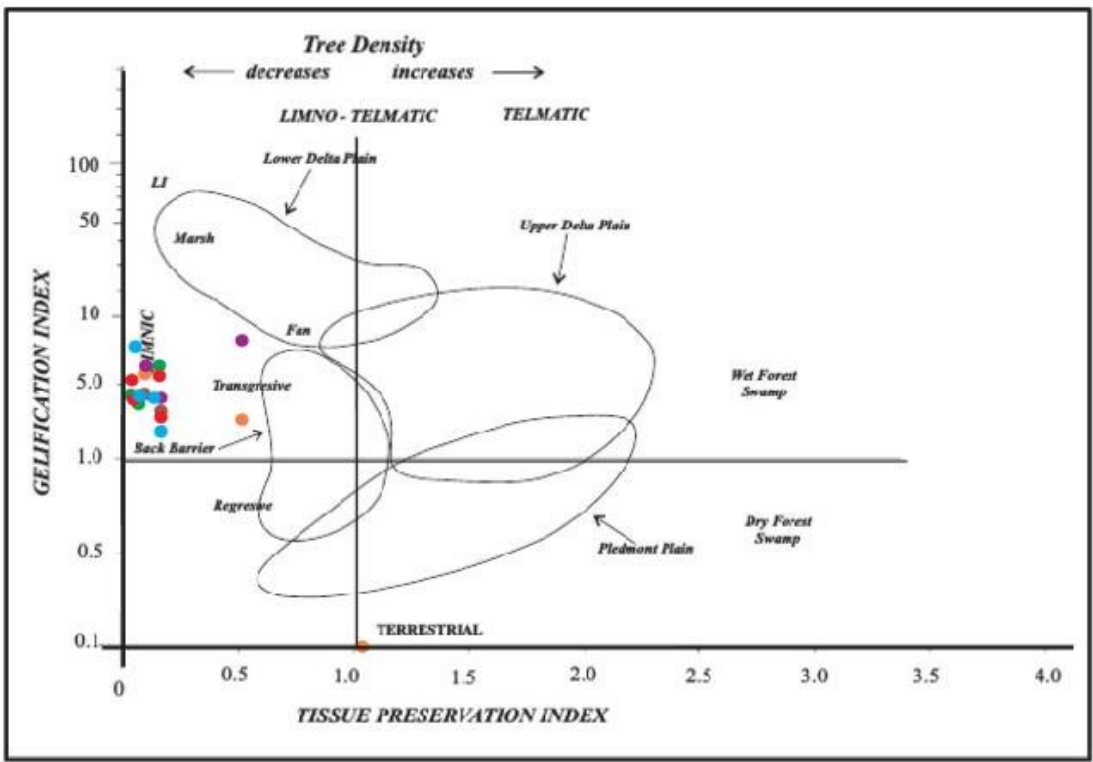

Fig. 3. Coal depositional facies Air Laya's mining Site using Diessel Diagram, 1986

\subsection{Relationship between TPI and Coal Quality}

The relationship between Inherent Moisture (IM) with TPI value (Fig. 4a) shows the trendline value i.e. $\mathrm{R}=0.3084$ which can be said to have enough correlation relationship. Relations between the two can suffice to be a preliminary prediction in determining the Inherent Moisture (IM) value of coal.

The relationship between the ash content (Fig. 4b) with the TPI value indicates the trendline value i.e. $\mathrm{R}=0.2652$ which can be said to have sufficient correlation relationship. Relations between the two can simply be said to be an initial prediction in determining the value of ash content on coal. It is known that ash content can be said to other material or mineral matter. In the results of the Maceral data shows a value of low mineral matterhence the relationship between the two is limited enough.

The relationship between Volatile Matter with TPI value (Fig. 4c) shows a trendline value that is $\mathrm{R}=0.8106$ which can be said to have a very strong correlation relationship. Based on the correlation, the value of TPI can be said to determine the value of Volatile Matter in coal. This is due to Volatile Matter having a relationship with vitrinite levels in coal.

The relationship between Fixed Carbon with TPI value (Fig. 4d) shows the trendline value i.e. $\mathrm{R}=0.3361$ which can be said to have enough correlation relationship. TPI is a value related to the humification rate at the time of coal deposition. The higher the degree of humification (woody plants) the higher the value of TPI, while the analysis of maceral is 
more dominant by detrovitrinite, which is a rupture of humus. Therefore, the relationship between the two can be quite said to be the initial prediction in determining the value of Fixed Carbon on coal.

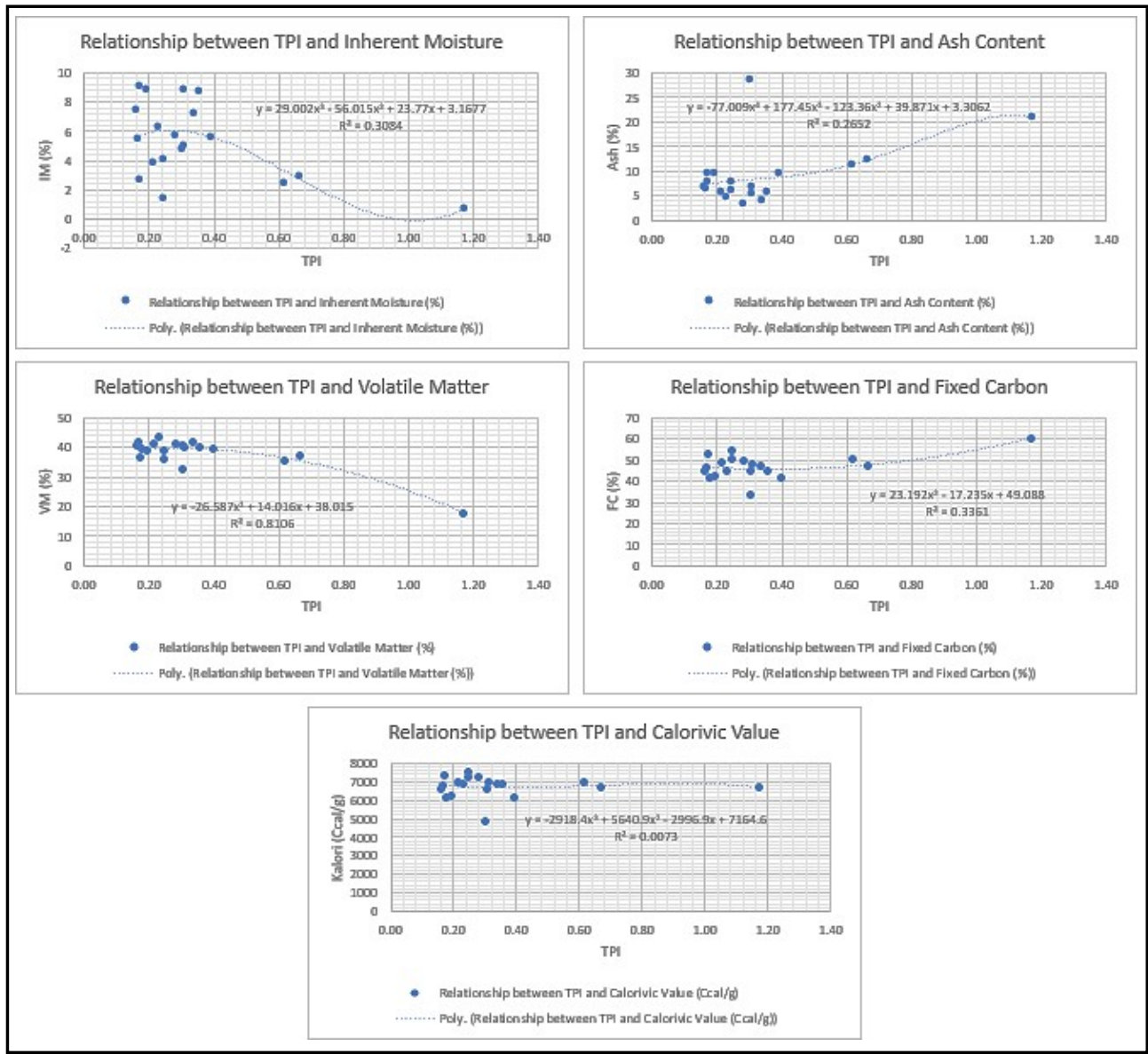

Fig. 4. Graph of TPI value relationship with Inherent moisture (a), TPI with ash content (b), TPI with Volatile Matter (c), TPI with Fixed Carbon (d), and TPI with Calorivic Value (e)

The relationship between calorie levels and TPI values (Fig. 4e) shows a trendline value of $\mathrm{R}=0.0073$ which can be said to have a very weak correlation relationship. Relations between the two cannot be said to be preliminary predictions in determining the value of calories in coal.

\subsection{Relationship between GI and Coal Quality}

The relationship between Inherent Moisture (IM) and the GI value (Fig. 5) indicates a trendline value of $\mathrm{R}=0.1961$ which can be said to have a very weak correlation relationship. The value of the GI is the value of humidity or the rate at which coal is deposited continuously while the value of Inherent Moisture (IM) is a value that indicates moisture content in coal. If it is referring to the depositional facies analysis which is a limnic facies where the environment is not affected by sea water and relies solely on the influence of rainwater and the fluvial of land as a process of its processing, which is indicated humidity occurs continuously. However, based on the geological state, the research area is indicated to have 
been affected by the intrusion process [7]. This is what causes the GI value to not relate strong enough with the Inherent Moisture (IM) value.

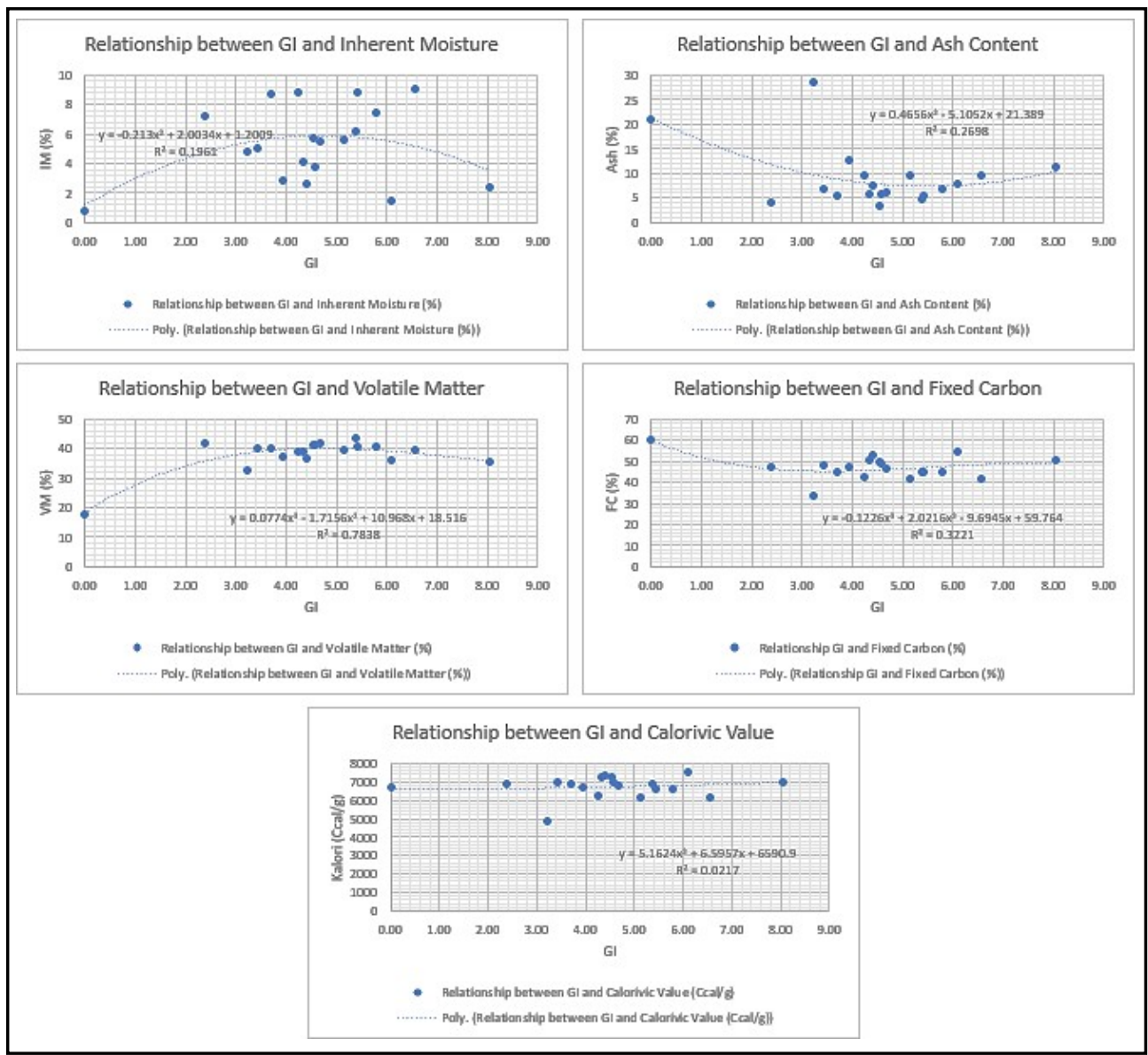

Fig. 5. Graph of GI value relationship with Inherent moisture (a), GI with ash content (b), GI with Volatile Matter (c), GI with Fixed Carbon (d), and GI with Calorivic Value (e)

The relationship between ash content and GI value (Fig. 5b) indicates a trendline value of $\mathrm{R}=0.2698$ which can be said to have sufficient correlation relationship. Generally, the content of ash content composition is caused by the coal deposition process, when the softsized classification of sediment is increasingly dominant, the intensity of the impurities (mineral matter) in the coal will be higher. Therefore, the relationship between the two can be fairly said to be the initial prediction in determining the value of ash content on coal.

The relationship between Volatile Matter with GI value (Fig. 5c) shows a trendline value of $\mathrm{R}=0.7838$ which can be said to have a very strong correlation relationship. Based on the correlation, the GI value can be said to determine the value of Volatile Matter in coal. This is because the value of the Gelification (GI) is a value that indicates the process of moisture intensity forming a layer of coal (gelification) in a swamp environment continuously. If coal formation is dominating by organic matter, then the elements of impurities such as flying substances in coal will be smaller. The more humid the state of the coal environment the more organic materials indirectly then the inorganic material is getting lower.

The relationship between Fixed Carbon and the GI value (Fig. 5d) indicates a trendline value of $\mathrm{R}=0.3221$ which can be said to have sufficient correlation relationship. The GI or 
gelification is the value of the humidity of peatland when coal is deposited, and moisture on the land is only based on the rain of poor nutrients. Therefore, the relationship between the two can be quite said to be the initial prediction in determining the value of Fixed Carbon on coal.

The relationship between the calorie rate and the GI value (Fig. 5e) shows a trendline value of $\mathrm{R}=0.0217$ which can be said to have a very weak correlation relationship. Relations between the two cannot be said to be preliminary predictions in determining the value of calories in coal.

\subsection{Relationship between TPI-GI and Rock Acidity}

TPI-GI In this case determine the environmental or depositional facies of the coal research area. The degree of humification (TPI) that is linked to the level of basing or (GI) will generate the type of swamp coal deposition area. The environmental deposition of the research area is on the limnic facies where the facies are located far from the marine environment and covered by the barrier. It is interpreted that the sulfide of the sea will not intervene in the rocks of the area. In addition, at GI values have a fairly high value, indicating that low oxidation levels are.

A limnic environment that has nothing to do with seawater [3] indicates that a minimal rock acidity process occurs. In other words, low acid mining water occurs in areas with the depositional environment. In addition, according to Ginger and Fielding (2005), the Muara Enim formation in the research area has a supply derived from land sediments and active hydrological systems that will protect rocks from seawater sulfide.

The low acidity of rocks affects the low acid water mining research area. This indicates that the state or condition of the research area still belongs to the environmentally friendly areas with normal water quality conditions and stable water organisms (no change in diversity).

\section{Conclusions}

The relationship of TPI-GI value to the quality of coal is the higher TPI value, the value of Inherent Moisture and Volatile Matter is getting lower and the value of ash content and Fixed Carbon is higher. The higher the value of the GI, then the value of ash content and Fixed Carbon is higher and the value of Volatile Matter is getting lower. In addition, the relationship between the value of TPI-GI to acid water mining is influential in the level of rock acidity where the correlation is associated with the coal depositional environment. The Limnic facies on the research area showed low acid water occurring because it was influenced by land sediment and active hydrological systems. The impact of the lack of acid water has caused low environmental pollution. In other words, the natural ecosystem during mining is still stable and awake. 


\section{References}

[1] Baihaqi, Azmi., Susilawati, Rita., Fauzielly, Lili., Muljana, Budi. 2017. Comparative study of Coal chemistry and petrography of field X, South Sumatera Basin and Indonesia Central Sumatran basin Y field. Geological Resource Bulletin Volume 12 number 2-(2017)

[2] Diessel C.F.K., Stoddart F.G. Geological Guide to BHP Saxonvale Mine. Excursion 2. ADV Stud Syd Bas, 20 Newcastle Symp Proc, pp 109-129 (1986)

[3] Diessel, C.F.K. Coal-bearing Depositional Systems. Berlin: Journal of Springer's Verlag 721p. (1992)

[4] Gandapradana. The PAF-NAF Deployment Final report in the Tanjung Enim mining area and surrounding areas. PTBA: South Sumatera. Unpublished (2017)

[5] Gautama, R.S. 2012. Acid water management. Technical guidance Presentation Slide reclamation and Post-mining on Mineral mining activities \& Directorate Minerals \& Coal. KESDM, Yogyakarta 20 June 2012

[6] Ginger, D. and Fielding, K., The petroleum systems and future potential of the South Sumatra Basin. Proceeding $30^{\text {th }}$ Annual Convention: Indonesia Petroleum Association (2005)

[7] Herbanu. Geology and influence of intrusion to the quality and geometry of coal layer Tanjung Enim and surrounding areas, Lawang Kidul, District Muara Enim, South Sumatera province. PT. Bukit Asam TBK, South Sumatera. Unpublished (2014)

[8] Horne, J.C., Ferm, J.C., Caruccio, F.T. and Baganz, B.P. Depositional Models in Coal Exploration and Planning in Appalachian Region. AAPG bulletin. (1978)

[9] Sardjito, Fadianto, Eddy, Djumlati, dan Hansen. Hydrocarbon prospect of the preTertiary basement in Kuang Area, South Sumatra. Proceedings IPA 20 th Ann. Convention. October 1991, p. 255-278 (1991)

[10] Sarwono, J. Quantitative and Qualitative research methods. Yogyakarta: Graha Ilmu (2006)

[11] Sukandarrumidi. Coal and Peat. Yogyakarta: Gadjah Mada University Press (1995) 